\title{
An Investigation of Mother Tongue Influence on EFL Learners during their Speaking Performance
}

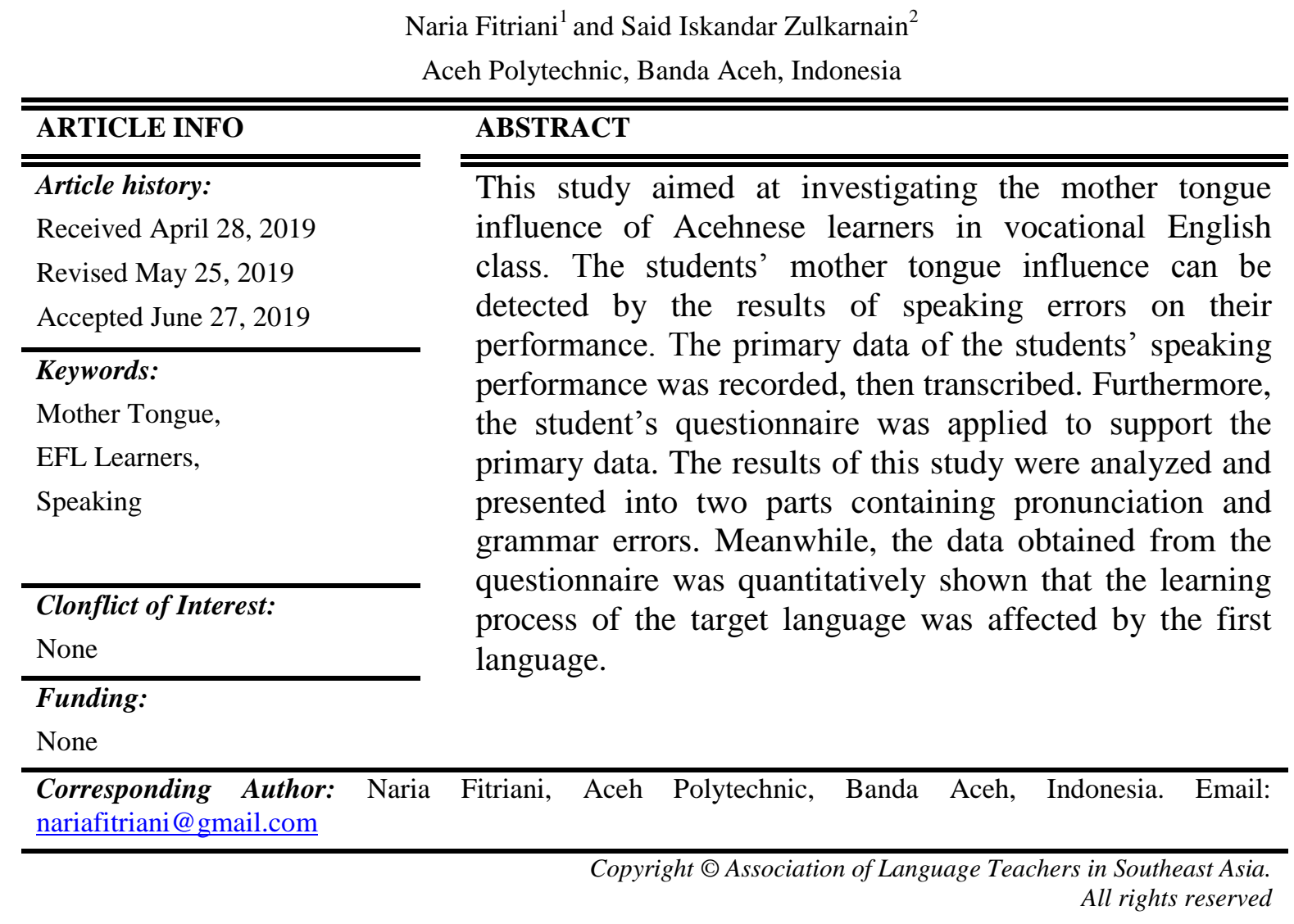

1. Introduction

Learning the foreign language has been a problematic situation for student recently. Though it is not an obligatory for students to master the L2 comprehensively, they are conscious adequately that learning English can be a benefit. During learning the language, it is undoubtedly supposed that there is an interlanguage process experienced for each learner. Consequently, student's mother tongue plays essential role during the target language practice.

As each of languages has its own rules, Indonesian and English structures are totally different in certain cases. For example, dissimilar with English, Indonesian have no verb changing which indicate the time. Sabbah (2015) revealed that learners having Arabic as their mother tongue made mistakes and errors in English learning process due to the negative transfer. He also provided some solution for teachers to reduce the students' mistakes. Furthermore, he differed in detail the Arabic and English language including tenses, pronouns, relative clauses, adverbs, adjectives, nouns, articles, pronunciation, and punctuation. In Indonesia, Sidupa (2018) evaluated the issue of language transfer in writing elementary class, whether L1 has an important role during language acquisition for Indonesian students. Through the study, he categorized several parts of the errors made by his students. These involved the root or simple present form, -ed overgeneralization, wrong spelling due to spoken target-like form, "tobe" omission, "did" overgeneralization, the use 
of "be" and the simple past or the "ing" form, blended forms, missselection of English verb form, and irregular simple past overgeneralization. Additionally, his study showed Indonesian has a great effect during the English acquisition. Conversely, in 2017, Khan, Shaheen \& Muhammad explored on 60 students having different mother tongues such as Saraiki, Punjabi, and Urdu relate to English learning. The results showed that the mother tongues have no significant influence to achieve the target language.

Not only grammatical errors are usually examined by researches in SLA, but also pronunciation errors have been a problematic issue to analyze. Sriphaba (2015: 299) found in his study that pronunciation errors were emerged during L2 acquisition owing to the difference of English sound system with the mother tongue. To overcome L1 interference, he suggested several activities students should do in example, identify the mother tongue influence, find the things of these influencing and keep practicing. On the other hand, Kelleher (2013) believed that mother tongue plays an important role in learning the target language. Instead of focusing on negative role in learning process, he agreed that mother tongue plays a positive role on it. In his study, the most students agreed that L1 was able to help them during L2 learning.

According to the previous literature reviews, this study investigated the mother tongue influence on English speaking class. The students contributing in this study were coming from several districts of Aceh such as Aceh Besar, Pidie, Aceh Utara, Aceh Barat, Aceh Selatan, Aceh Tengah, Simeulu, Gayo Luwes. The pronunciation and grammar errors were examining in order to find the role of L1 during the target language acquisition by analyzing their communicative competence. Last but not least, the students' view of learning process due to the mother tongue influence was also presented.

\section{Research Method}

In this study, mixed method was designed to merge the results on the student's speaking performance and questionnaire in order to answer the problems accurately. The total of students participating in this study was 25 . It involved all of the students in one of Banda Aceh college taking English in their last year of study. The data used in this study contained the students' audio recording and the students' questionnaire. To identify the students' language interference, they were required to show their English speaking ability by recording it. The topic they recorded was about their experience in their childhood. All of students needed to submit the tasks before the questionnaire was distributed. During the data obtained, it kept being checked every item of the questionnaire. The question on the questionnaire was adopted from Gan (2013). The primary data from the students' audio recording was transcribed and analyzed while the questionnaire was employed to strength the main data. The qualitative and quantitative data were analyzed separately then they were compared and interpreted (Creswell, 2014:270). Finally, the data from recording and questionnaire were displayed and discussed in detail based on the following subtopic.

\section{Results and Discussion}

\subsection{Results on Speaking Performance}

The students' mother tongue influence can be identified by the results of speaking errors on their performance. In this case, the students' performance on their communicative competences were recorded and transcribed. Based on the data displayed below, it can be stated that most students have pronunciation problems on the target language. Their mother tongue seems interrupted their English articulation. In this subtopic, the errors of students' pronunciation might be divided into the errors on vowel and consonant. In this study, the errors pronunciation is discussed in the context of the students' mother tongue influence.

E $1 \quad$ :.../'hæf.i/ was pronounced for the word 'happy' /'hæp.i/ 
... /flei / was pronounced for the word 'play' / plei/

E $2 \quad: . . . / \mathrm{tm} / \mathrm{w}$ was pronounced for the word 'thing' $/ \theta \mathrm{my} /$

E $3:$ :.../ridin/ was pronounced for the word 'riding' /'rsidin/

E $6:$ :... /montain/ was pronounced for the word 'mountain' /' maontın/

E $9: \ldots$ rəs/ was pronounced for the word 'race'/reIs/

E $10: . . . /$ tirət was pronounced for the word 'tired' /taiəd/

E $11: .$. /arivət was pronounced for the word 'arrived' /a'raivd/

E $12: .$. /yusət/ was pronounced for the word 'used'/ju:st/

... /hik/ was pronounced for the word 'high' /hai/

E $13: \ldots / \mathrm{rrd} /$ was pronounced for the word 'ride' / $\mathrm{raId} /$

... /usali/ was pronounced for the word 'usually' /'ju:.zu.ə.li/

... /kareful/ was pronounced for the word 'careful' /'keə.fəl/

E $18: .$. /crl-aut/ was pronounced for the word 'childhood' /'t farld.hod/

E $19:$ :... /weit/ was pronounced for the word 'with' /wıð/

... /daI/ was pronounced for the word 'day'/deI/

... /imeditely/ was pronounced for the word 'immediately' /I'mi..di.ət.li/

... /snek/ was pronounced for the word 'snake' /snerk/

... /lef/ was pronounced for the word 'life' /lauf/

E $20: \ldots$ lau/ was pronounced for the word 'laugh' /la:f/

E $21: \ldots / \mathrm{bal} /$ was pronounced for the word 'ball'

... /lauk/ was pronounced for the word 'laugh' /la:f/

... /bihən/ was pronounced for the word 'behind' /bi 'haind/

E $23: .$. /clottəs/ was pronounced for the word 'clothes' /kləøðz/

... /haik/ was pronounced for the word 'high' /hai/

... /injurət/ was pronounced for the word /' In.dzod/

E $24: \ldots /$ nən/ was pronounced for the word 'nine' /nain/

... /yoy/ was pronounced for the word 'young'/j $1 \mathrm{y} /$

... /hors/ was pronounced for the word 'hours' /'avəz/

E $25: \ldots$ /crlhot/ was pronounced for the word 'childhood' /'t farld.hod/

According to the data, it is clearly found that the students did the errors on the vowels pronunciations such as /o/, /e/,/i/, / / /, /ai/ and /au/. While the student 1 articulated /æ/ in the words 'happy' and 'play' properly, he/she seems have problem on the consonant pronunciation, particularly on $/ \mathrm{p} /$. From the audio recording, the two words were stated faultily owing to his/her background. From the transcription of his/her spoken performance, it was voiced that the student came from Gayo Luwes. Mathew (1997) did the study on Gayo students then proved that Gayo lays on a peak in initial /p/ of the pronunciation. In the reading test, he found that Gayo made errors on /p/ by saying /f/ or $/ \mathrm{v} /$ more than others. Consequently, it is determined that the student cannot be differed how to say /p/ or /f/ at the same time.

On the other hand, student 3 , student 10 , student 11 , student 13 , student 18 , and student 25 generalized the vowels $/ \Lambda \mathrm{I} /, / \mathrm{aI} /$, and $/ \mathrm{aI} /$ as $/ \mathrm{I} /$. It is obviously exemplified that the students had less understanding on the English vowels sounds. Rather than articulating the vowels 
as $\Lambda \mathrm{I} /, / \mathrm{aI} /$, and $/ \mathrm{aI} /$, the students globalized the sound as /I/. On the other hand, student 6 inclined to utter /aI/ for the word 'day' /deI/, while student 9 omitted /I/ in the /reis/. These facts expressed that the students tend to say the English words erroneously owing to the lack of practicing. Moreover, interference of L1 can be the other reasons of the errors results. Dealing with, Subandowo (2017) investigated some factors of mother tongue influence on university students in Indonesia. His study concerned on the language interference on speaking English. He found that students' pronunciation was interfered by some factors containing the environment, students' motivation, different sounds and different sound symbol. In the other case, Lord (2008) stated that L1 and L2 merged each other in language output. He described that an English person having good Spanish ability usually pronounce Spanish words by "English-like".

Unlike English consonant sound, Aceh or Indonesian has no exist of the sounds such as $/ \theta /$, and $/ \delta /$. It was found on the data that student 2 , student 19 , and student 23 were not able to say the sound correctly. Still, these results concurred that the students had a large effect of their first language.

Although the English sounds errors were dominantly found in this study, there were some data showed the grammar of L1 influence during the language acquisition. The following data were displayed the students' English structure which E refers to excerpts from data.

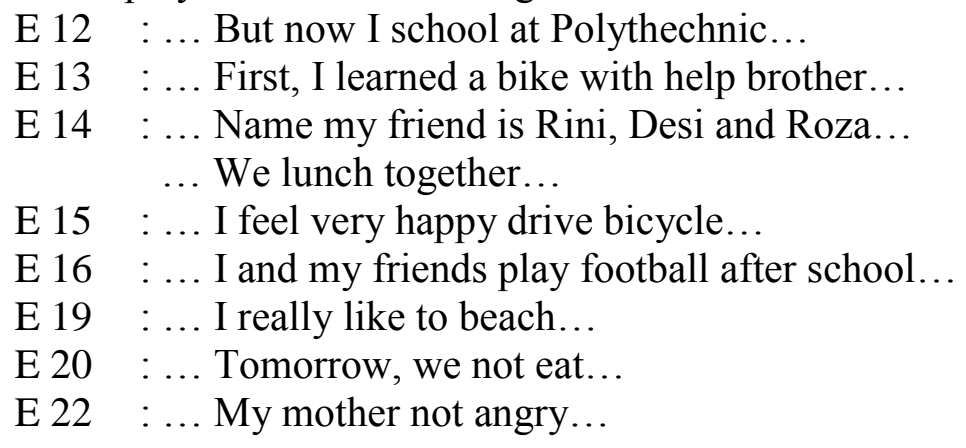

According to the data recorded above, it is obviously demonstrated that most students were obstructed by the first language. Student 12 stated "but now I school at Polytechnic..." which means that he/she was not aware of the word "school". The student did not realize that the "school" must not put as the predicate. Meanwhile, student 13 has stated with the accurate predicate yet he/she uttered the complement incorrectly. Student 14 did the similar error with student 12 by saying noun (lunch) as the predicate. Additionally, he/she arranged the words on inappropriate order of the sentence by speaking "name my friend is Rini, Desi and Roza." In other cases, student 15 uttered the language part smoothly but he/she used the wrong collocation (drive is not for bicycle). For student 16, though the language has been good, English is not expressed the other object (my friends) after "I". The other cases of student 19 and 20 which attempted to communicate in English accurately nonetheless the Indonesian as their L1 was distracted their language output.

Based on the previous results showed, it is positively presented that the students' mother tongue has a dominant role in the English structure. Although the students employed English in their speaking performance, the Indonesian structure was revealed. To agree with, Carrió-Pastora \& Vallésb (2015) study was also detected that the mother tongue influence in language acquisition. Furthermore, Azizah (2016) indicated that the highest students' problems in speaking are vocabulary limitation, nervousness, fear, grammar and fluency. She also stated that mother tongue has a substantial influence in the language acquiring process. Meanwhile, Nurhayati, et al. (2016) studied on Indonesian college students having impediment(s) in language learning particularly speaking English. They found the students' problems on misuse of tenses, the misuse of verb, the misuse of 
agreement, the misuse of word order, and the wrong of chosen word. Their study also noticed that L1 impacts on learning new language.

\subsection{Results on Student's Questionnaire}

On the student's questionnaire (see appendix 1), not only 'yes' and 'no' answer was available, but also the students' comments towards their learning experiences were elaborated. In the other words, the students might respond with their opinions though via writing. The results illustrated that most of students agree with the statement. There were $88 \%$ of students answered that they thought in their mother tongue when speaking English. Meanwhile, only $12 \%$ of the students disagreed with the statement on the questionnaire. Consequently, the results of this instrument showed clearly that the first language has an important role during the language acquisition.

According to the data analyzed, the majority of the students noted several opinions to strengthen their 'yes' answers. The large number of them stated that they thought Indonesian then translated into English. They strongly agreed that the mother tongue is easier to understand so that Indonesian is used if they do not know the English version. Meanwhile, a student said that he/she needs to think several times which means that he/she keeps thinking the language before speaking. The other one said that he/she was afraid to utter the English faultily. Finally, another student added that he/she cannot speak English well so he/she thought the L1 while practicing English in the classroom.

To argue with the explanation above, a student described that English and Indonesian is not the same. The structure of English is different with Indonesian in which English is usually inversed from Indonesian. Moreover, he/she believes that the L1 was no need to think in advanced during the English communicative competence. Nation (2003: 5) explained the correlation between L1 and L2. He stated that L1 is a practical tool which students can be used whenever they need yet it should not be over-used. On the other hand, Mede et.al (2014) ascertained the effect of language transfer during English learning process in a university in Turkey. Their study showed the negative transfer between Turkish and English in word order patterns particularly in the use of action verbs.

\section{Conclusion}

This qualitative-quantitate study concerned on the mother tongue influence in English acquisition for Acehnese students in a vocational school. The data involving students' audio recording and questionnaire were analyzed and displayed. To examine the mother tongue influence, the students' errors pronunciation and grammar were presented. From the students' oral performance, the results illustrated that the greatest number of the students English pronunciation was influenced by their L1. Meanwhile, the grammar errors affected by L1 interference were not found as many as the pronunciation errors.

\section{References}

Azizah, I. (2016). An Analysis of Students' Difficulties in Speaking English: A Case Study at Eleventh Grade Students of MA Al- Muslimun NW. (Unpublished Journal). University of Mataram.

Carrió-Pastora, M. L. \& Vallésb, I. T. (2015). A comparative study of the influence of the mother tongue in LSP and CLIL. 15th International Conference of the Spanish Association of language and Literature Education, 15th International Conference SEDLL: Procedia - Social and Behavioral Sciences, 178, 38 - 42.

Creswell, W. J. (2014). Research Design: Qualitative, Quantitative and Mixed Methods Approaches. $4^{\text {th }}$ ed. Thousand Oaks, California: SAGE Publications, Inc. 
Gan, Z. (2013). Understanding English speaking difficulties: An investigation of two Chinese populations. Journal of Multilingual and Multicultural Development, 34(3), 231-248.

Kelleher, M. (2013). Overcoming the First Language Taboo to Enhance Learning a Foreign Language. 3rd World Conference on Learning, Teaching and Educational Leadership (WCLTA). Procedia - Social and Behavioral Sciences 93, 2037 - 2042

Khan, A. M. R., Shaheen, R., \& Muhammad, S. (2017). Impact of Mother Tongue on Learning English Language on Secondary School Level Students. Journal of Literature, Languages and Linguistics, 31: 15-18.

Lord, G. (2008). Second Language Acquisition and First Language Phonological Modification. The 10th Hispanic Linguistics Symposium, ed. Joyce Bruhn de Garavito and Elena Valenzuela, 184-193.

Mathew, I. B. (1997). Errors in pronunciation of consonants by Indonesian, Gayo and Acehnese learners of English as a foreign language. Retrieved from https://ro.ecu.edu.au/theses/904

Mede, E., Tutal, C., Ayaz, D., Calışır, K., \& Akın, Ş. (2014). The Effect of Language Transfer in Turkish EFL Learners. ELT Research Journal, 3(2), 70-83.

Nation, P. (2003). The role of the first language in foreign language learning. ASIAN EFL Journal, 5(2), 1-18.

Nurhayati, W. A. D., Djatmika., Santosa, R., \& Wiratno, T. (2016). Indonesian Influence in Developing Speaking Skill in Learning English: EFL Learners' Impediments. International Seminar Prasasti III: Current Research in Linguistic, 207-211.

Sabbah, S. S. (2015). Negative Transfer: Arabic Language Interference to Learning English. Arab World English Journal, 4, 269-288.

Sidupa, C. (2018). Indonesian Language Transfer of Students of English as a Second Language (ESL). The 1st International Seminar on Language, Literature and Education, KnE Social Sciences, 51-57.

Sriphaba, M. (2015). A Study on Mother Tongue Influence in English Communication. International Journal of English Literature and Culture, 3(11), 296-300.

Subandowo, D. (2017). The Language Interference in English Speaking Ability for EFL Learners. Proceedings of the Fifth International Seminar on English Language and Teaching (ISELT-5), 205-210.

Appendix 1 Results to Students' Opinion about L1 Interference

\begin{tabular}{c|c|c|c}
\hline \multicolumn{1}{c|}{ Student's Experience } & Answer & Total & Percentage \\
\hline \multirow{2}{*}{ I think in my mother tongue when speaking English } & Yes & 22 & $88 \%$ \\
\cline { 2 - 4 } & No & 3 & $12 \%$ \\
\hline
\end{tabular}

